\title{
PAUTAS PARA PUBLICAR EN LA REVISTA EAN
}

\section{Enfoque y alcance}

La Revista Escuela de Administración de Negocios es una publicación de carácter científico y académico, editada semestralmente por la Universidad EAN. Su objetivo principal es la publicación de trabajos resultado de investigación que se articulen con el interés tanto del medio académico como el empresarial, y que aporten a los debates en el campo de las ciencias sociales, específicamente en el área de la economía y los negocios.

Su público objetivo son los profesionales, académicos, investigadores y estudiantes, que buscan actualizarse en contenidos relacionados con los ejes temáticos que aborda la publicación.

https://doi.org/10.21158/01208160

\section{Pautas para autores}

\section{Tipología}

Los artículos que sean enviados a la Revista Escuela de Administración de Negocios, deben estar dentro de una de las siguientes categorías, tomadas de las especificaciones presentadas por Colciencias -Publindex:

\begin{tabular}{|c|l|}
\hline Tipo de artículo & \multicolumn{1}{c|}{ Descripción } \\
\hline $\begin{array}{c}\text { Artículo de investigación científica y } \\
\text { tecnológica }\end{array}$ & $\begin{array}{l}\text { Documento que evidencia resultados originales de un proyecto } \\
\text { de investigación concluido. La estructura generalmente utilizada } \\
\text { contiene cuatro apartes importantes: introducción, metodología, } \\
\text { resultados y conclusiones. }\end{array}$ \\
\hline \multirow{2}{*}{$\begin{array}{l}\text { Artículo de revisión } \\
\text { analizan, sistematizan e integran los resultados de investigaciones } \\
\text { publicadas o no publicadas, sobre un campo en ciencia o tecnología, } \\
\text { con el fin de dar cuenta de los avances y las tendencias de desarrollo. } \\
\text { Se caracteriza por presentar una cuidadosa revisión bibliográfica de } \\
\text { por lo menos 50 referencias. }\end{array}$} \\
\hline Reporte de caso & $\begin{array}{l}\text { Documento que presenta los resultados de un estudio sobre una } \\
\text { situación puntual, para dar a conocer las experiencias técnicas y } \\
\text { metodológicas consideradas en un caso específico. Debe incluir una } \\
\text { revisión de literatura sobre casos análogos. }\end{array}$ \\
\hline
\end{tabular}




\section{Estructura general de los artículos}

Los datos indispensables que debe incluir todo artículo postulado son:

- Nombre(s) completo(s) del autor(es).

- Filiación institucional actual (académica).

- Correo electrónico.

- Breve biografía académica, en la que se especifiquen únicamente los títulos académicos y universidad de la cual fueron obtenidos.

- Código ORCID (Obligatorio).

Además de ello, se sugiere que el artículo se estructure de la siguiente manera:

\section{- Título.}

Debe ser conciso y describir el contenido del artículo en forma clara y precisa, de tal manera que el lector identifique el tema fácilmente.

\section{- Resumen.}

Debe ser en español y debe tener entre 200 y 250 palabras. En caso de que el artículo esté escrito en inglés, francés o portugués, también debe remitirse el resumen en su idioma original. Se trata de una síntesis del objeto de estudio, los objetivos, la metodología y las conclusiones o hallazgos más relevantes. No debe incluir referencias bibliográficas ni notas a pie de página.

\section{- Palabras clave.}

Deben oscilar entre los seis y diez ítems. Deben ser remitidas en español.

- Cuerpo del artículo.

Como elementos fundamentales debe contener: introducción, metodología, resultados, discusión, conclusiones y referencias.

\section{Formato de presentación de los artículos}

- Formato: carta $(21.5 \mathrm{~cm} \times 27.9 \mathrm{~cm})$.

- Márgenes: Sup. $2.5 \mathrm{~cm}$. Inf. $2.5 \mathrm{~cm}$. Izdo. $2.5 \mathrm{~cm}$. Dcho. $2.5 \mathrm{~cm}$.

- Fuente: Arial.

- Tamaño de fuente: 12 puntos.

- Interlineado: 1.5 .

- Columnas: 1.

- Procesador: Word.

- Extensión del artículo: entre 17 y 25 páginas (sin contar lista de referencias) 


\section{Otros aspectos a tener en cuenta}

\section{- Normas de citación}

La revista emplea una adaptación de la American Psychology Association (APA) como norma en lo referente a citación, referenciación y presentación de figuras y tablas. Se sugiere utilizar como guía específica el Manual de citación y referenciación de la universidad EAN, disponible en https://bit.ly/2Pieldx

- Nomenclatura de títulos y subtítulos

Se refiere a la numeración de los apartados y va jerarquizada en niveles diferenciados por números y estilos así:

\section{Título del artículo (mayúscula inicial, centrado y en negrita)}

\section{Título de apartado (Justificado a la izquierda en negritas)}

\subsection{Subtítulo primer nivel (Justificado a la izquierda, con sangría, en negritas)}

1.1.1 Subtítulo segundo nivel. (Justificado a la izquierda, con sangría, con punto al final)

1.1.1.1 Subtítulo tercer nivel. (Justificado a la izquierda, con sangría, en itálicas con punto al final)

\section{- Figuras y tablas}

Se entiende como figura todo aquel material gráfico utilizado en el artículo —imágenes, fotografías, diagramas, etc.-

Se entiende como tabla, toda la información, estadística, numérica o de comparación conceptual, dispuesta dentro de un recuadro, con filas y columnas.

Tanto las figuras como las tablas deben ser numeradas de forma consecutiva, según su orden de aparición dentro del texto - tablas y figuras con consecutivo independiente-; deben tener un título que describa brevemente su contenido y la referencia precisa de la fuente donde fue obtenida. El formato para dicha información debe ser el siguiente:

Figura 1. Capilla sixtina

Fuente. Gombrich, 1950. (Si es tomada de alguna fuente)

Fuente. Elaboración propia. (Si es creación del autor/autores)

Figuras y tablas deben ser remitidas en escala de grises, por ello, se debe tener en cuenta que la información allí representada sea lo suficientemente clara y fácil de distinguir.

Además de presentarse en el cuerpo del texto, deben enviarse en un archivo adicional en el formato de origen en el que fueron creados y en escala de grises, no a color. La resolución debe ser de 300dpi como mínimo.

\section{- Notas a pie de página}

Las notas de pie de página deben ser únicamente de carácter aclaratorio. Todos los datos concernientes a referencias bibliográficas deben ir dentro del cuerpo de texto y registradas en la lista de referencias. 


\section{- Referencias}

Todos los textos y autores que se mencionen en el cuerpo del texto deben registrarse en la lista de referencias y todos los elementos que estén registrados en la lista de referencias deben estar incluidos en el cuerpo del texto. Las fuentes de figuras y tablas también deben registrarse allí, en caso de que no sean de elaboración propia.

La lista de referencias se ubica al final del documento y debe organizarse por orden alfabético, según apellido. En caso de que se deban referenciar varias publicaciones del mismo autor, estas deben ir organizadas en orden cronológico, según año de publicación. Cuando existan varias publicaciones de un mismo autor cuya fecha de publicación sea el mismo año, deben diferenciarse de la siguiente manera:

López, J. (2018a)

López, J. (2018b)

Para el caso de artículos de revistas científicas y académicas se solicita incluir el DOI, cuando este se encuentre disponible.

Para el caso de fuentes digitales se solicita proporcionar la URL y verificar que la misma se encuentre en funcionamiento.

A continuación, se presentan algunos ejemplos del formato de referenciación que debe utilizarse:

\section{Artículos en publicaciones periódicas:}

\section{- Digitales}

Martínez, J. (2017). El conocimiento como sistema adaptativo complejo en las organizaciones de gestión de proyectos - PMO. Revista Ontare, 4(2), 27-54. DOI: https://doi.org/10.21158/23823399.v4.n2.2016.1626

Castro-Silva, H.; Diez-Silva, H.; Quijano-Brand, L. (2013). Plan de gestión de costos en dirección de proyectos: aplicación en una empresa del sector minero-industrial de Colombia. Revista Escuela De Administración de Negocios, (74), 22-39. DOI: https://doi.org/10.21158/01208160.n74.2013.734

- Impresas

Solans, A. (1998). ¿Es el management una ciencia? un programa de diez preguntas para reflexiona. Revista Escuela de Administración de Negocios, (35), 4-20.

Velasco-Duarte, N.; Leguízamo-Vanegas, D. (2017). Arte y educación, un nuevo camino para la formación de públicos en las ferias de arte de América. Comunicación, Cultura Y Política, 7(1), 129-158.

\section{Libros:}

- Impresos

Moreno-Monsalve, N. A.; Diez-Silva, H.M. (Eds.) (2018). La gerencia de proyectos como impulsor de la estrategia organizacional. Bogotá: Universidad EAN.

Nagles-García, N.; Gil-Toledo, J. J.; García-Durán, H.; Melo-Melo, C. M.; Vélez-García, R. D.; Reyes-López, O.; Romero-Rincón, J. C. (2018). Innovación y emprendimiento en la educación superior. Bogotá: Universidad EAN. 


\section{- Digitales}

Martínez-Sepúlveda, J. A.; Casallas, M. R. (2018). Contaminación y remediación de suelos en Colombia. Aplicación a la minería de oro. Bogotá: Universidad EAN. Recuperado de http://editorial.universidadean. edu.co/acceso-abierto/contaminacion-y-remediacion-de-suelos-en-colombia.pdf

\section{- Capítulo de libro dentro de compilación}

Menchero-Sánchez, M. (2017). Ciudades históricas, turismo cultural y cooperación internacional desde un enfoque teórico-conceptual. En C. A. Zambrano-Barrera (Comp.) Cinco miradas al turismo cultural. (15-60). Bogotá: Universidad EAN.

\section{Legislación:}

- Ley 1450 de 2011. (16 de junio de 2011). Por la cual se expide el Plan Nacional de Desarrollo, 2010-2014. Diario Oficial, núm. 48102. Congreso de Colombia.

- Decreto 1075 de 2012. (22 de mayo de 2012). Por el cual se reglamenta la organización y funcionamiento de los Órganos Colegiados de Administración y Decisión y las secretarías técnicas, de acuerdo con lo establecido en el artículo $6^{\circ}$ de la Ley número 1530 de 2012. Diario Oficial, núm. 48438. Departamento Nacional de Planeación.

\section{Tesis:}

Membrado-Corma, C. (2016). Proyecto TIC-TAC, aprendiendo a hacer ciencia (Tesis de maestría). Universitat Jaume I. Castelló de la Plana, España. Recuperado de https://bit.ly/2DMgVRv

\section{Documentos técnicos:}

Departamento Administrativo de Ciencia, Tecnología e Innovación. (18 de diciembre de 2015). Modelo de medición de grupos de investigación, desarrollo tecnológico o de innovación y de reconocimiento de investigadores del sistema nacional de ciencia, tecnología e innovación, año 2015. Bogotá, Colombia. Recuperado de https://bit. ly/2WYTaxx

\section{Ponencias en eventos:}

Vélez-Álvarez, C.; Giraldo-Zuluaga, L. F. (2018). Evaluación de publicaciones científicas con calidad: una experiencia de una Universidad Pública Colombiana. Ponencia presentada en el 3er Congreso Internacional de Editores Redalyc. Universidad César Vallejo, Trujillo, Perú, 16-18 de mayo.

\section{Prensa:}

- Impresa con autor

Schuartz, J. (30 de septiembre de 1993). Obesity affects economic, social status. The Washington Post, A1, A4.

\section{- Impresa sin autor}

Obesity affects economic, social status. (30 de septiembre de 1993). The Washington Post, A1, A4.

\section{- Digital con autor}

Cala, P. (01 de mayo de 2019). Si has sido testigo, ¿qué has hecho para transformar tu realidad? El Espectador. Recuperado de https://bit.ly/2H9Fr0W 


\section{- Digital sin autor}

Si has sido testigo, ¿qué has hecho para transformar tu realidad? (01 de mayo de 2019). El Espectador. Recuperado de https://bit.ly/2H9FrOW

\section{Páginas de internet:}

\section{- Con fecha conocida}

Universidad EAN. (07 de mayo de 2019). Sector de las TIC en Colombia, un mundo de oportunidades laborales. Recuperado de https://bit.ly/2Vekfuu

\section{- Con fecha desconocida}

Universidad EAN. (s.f.). Sector de las TIC en Colombia, un mundo de oportunidades laborales. Recuperado de https://bit.ly/2Vekfuu

\section{Proceso de evaluación}

Los artículos postulados a la Revista Escuela de Administración de Negocios son sometidos a un completo proceso de evaluación, que tiene como criterios generales de selección la pertinencia temática, la calidad científica, la originalidad, la claridad en la argumentación y el cumplimiento de los parámetros de presentación de artículos establecidos por la revista, con el fin de garantizar la calidad y el rigor científico de la publicación. A continuación, describimos con detalle dicho proceso.

Una vez definidos tanto los ejes temáticos de las ediciones del año, como la proyección del calendario editorial por parte del Comité Editorial de la revista, se procede a lanzar las respectivas convocatorias, de alcance nacional e internacional, para recepción de artículos.

Tras el cierre de la convocatoria, el Comité Editorial se reúne para realizar en MODALIDAD DOBLE CIEGO el proceso de verificación de requisitos iniciales de los artículos, con relación a su tipología, el cumplimiento de las pautas de presentación de artículos de la revista y el foco temático de este.

Luego de este primer filtro de evaluación, se realiza la respectiva notificación a la totalidad de los autores y aquellos textos que han superado esta primera etapa continúan con la fase de revisión y evaluación en MODALIDAD DOBLE CIEGO, por parte de pares externos.

La selección de los pares externos se realiza en función de su conocimiento y experticia con respecto a la temática del texto a evaluar. Dicha búsqueda se realiza a través de la base de datos de colaboradores externos de la publicación -que se encuentra en constante actualización - y la base de datos de árbitros de Colciencias.

La evaluación se realiza mediante el formato establecido por la revista, que se envía a los pares junto al texto, las indicaciones generales de diligenciamiento y la notificación de los plazos establecidos para realizar la respectiva revisión y evaluación.

Los dos ejes alrededor de los cuales se articula la evaluación son la estructura formal y la calidad del contenido, los cuales de dividen a su vez en una serie de elementos que se califican de forma numérica-de 1 a 5 , siendo 1 el menor valor y 5 el mayor-, y que en su suma final arrojan un puntaje que determina la valoración y el concepto frente a la publicación del artículo de la siguiente manera: 


\begin{tabular}{|c|c|c|}
\hline CALIFICACIÓN & VALORACIÓN & CONCEPTO \\
\hline $100-90$ & EXCELENTE & Publicable y no requiere ajustes. \\
\hline $89-80$ & MUY BUENO & Publicable con ajustes mínimos. \\
\hline $79-70$ & BUENO & Publicable con ajustes nivel medio. \\
\hline $69-60$ & ACEPTABLE & Publicable con ajustes significativos. \\
\hline $59-0$ & NO ACEPTABLE & No es publicable. \\
\hline
\end{tabular}

De acuerdo al concepto emitido por el par, se procede a realizar la notificación al autor o autores, con la respectiva retroalimentación de las observaciones y sugerencias emitidas mediante la evaluación y la solicitud de ajustes, si se requieren. En este último caso, se determina un plazo específico de entrega y posteriormente se realiza un proceso de verificación de dichos ajustes, a cargo de los pares evaluadores.

En caso de presentarse controversia de cualquier tipo, es el editor, en conjunto con el Comité editorial, la instancia que dirime la situación y entrega veredicto final al respecto.

\section{Tiempo estimado para la evaluación}

Con el objetivo de garantizar un correcto y riguroso proceso de evaluación en cada una de sus fases, se estiman los siguientes tiempos promedio de entrega de veredictos.

- Primera fase - Comité editorial: dado que esta fase se lleva a cabo al finalizar el periodo de convocatoria, una vez se han compilado el total de artículos participantes en el proceso editorial y que las reuniones se programan coordinando las agendas de sus miembros de acuerdo a su tiempo disponible, el tiempo promedio de respuesta es de 3 meses, aproximadamente.

- Segunda fase - Pares externos: teniendo en cuenta los tiempos de aceptación a las invitaciones que se realizan a pares externos y la disponibilidad de los mismos para llevar a cabo las lecturas, se estima que el tiempo promedio del veredicto en esta fase sea de 3 meses, aproximadamente.

\section{Sobre los derechos de autor}

Los artículos postulados deberán ser originales e inéditos y no podrán tener ningún compromiso editorial de publicación, ni deben encontrarse en proceso de evaluación simultáneo por parte de otra publicación o entidad. En el caso de usar fotografía o imágenes, se deben enviar los respectivos permisos de uso y publicación de estas. El autor o autores, deberán autorizar la publicación de su texto a través del diligenciamiento y firma del formato de «Autorización de la publicación a favor de la Universidad EAN». Dicho formato es suministrado por la editorial una vez el artículo ha superado satisfactoriamente las dos etapas de evaluación y ha sido aprobado para publicación.

Los autores de artículos que se publiquen en la revista, tendrán derecho a recibir dos ejemplares físicos del mismo número en el que apareció su aporte.

En cualquier caso, el Comité Científico y Editorial de la revista entiende y declara que las opiniones expuestas por los autores, son de exclusiva responsabilidad de estos. 


\section{Frecuencia}

La Revista Escuela de Administración de Negocios es una publicación de frecuencia semestral, que publica sus ediciones de la siguiente manera:

- Enero a junio.

- Julio a diciembre.

\section{Política de acceso abierto}

La Revista Escuela de Administración de Negocios proporciona acceso libre y permanente a sus contenidos, basado en el principio de intercambio global del conocimiento. En este mismo sentido, la publicación no exige ningún tipo de pago ni compensación, ni por la postulación, ni por la evaluación, ni por la publicación de artículos. El contenido de la revista está bajo una licencia de Creative Commons Reconocimiento-NoComercialSinObraDerivada 4.0 Internacional.

La Revista Escuela de Administración de Negocios permite el autoarchivo, por parte de los autores, de sus artículos publicados, en repositorios temáticos o páginas web personales, una vez que se encuentre la versión final en PDF publicada en nuestra plataforma. No se autoriza el autoarchivo o publicación de los manuscritos, ni las versiones previas a diagramación de los textos.

\section{Política de preservación de archivos digitales}

La preservación de archivos digitales de la revista se lleva a cabo a través de LOCKSS y CLOKSS.

\section{Indexación}

Actualmente, la revista se encuentra indexada en DOAJ (Directory of Open Access Journals), SciELO (Scientific Electronic Library Online), Redalyc (Red de revistas científicas de América Latina y el Caribe), REDIB (Red Iberoamericana de innovación y conocimiento científico), EBSCOhost, EconLit, y en el índice nacional Publindex de Colciencias en la categoría B.

\section{Historia de la revista}

En el año de 1986 nace la Revista Escuela de Administración de Negocios, como una iniciativa institucional para la difusión del conocimiento que surgía del trabajo científico de sus docentes e investigadores. Desde entonces hasta hoy, la publicación ha atravesado varias etapas de cambio, que han involucrado entre otros elementos: la definición de las ciencias sociales como su campo académico de acción y de la economía y los negocios como área temática específica; la apertura de su espacio a profesores e investigadores de distintitas instituciones y la entrada al mundo de las publicaciones digitales. 


\section{Guideline to publish an article in the EAN Journal}

\section{Approach and scope}

The Escuela de Administración de Negocios Journal is a scientific and academic publication, produced on a biannual basis by the Universidad EAN. Its main objective is the publication of works resulting from research that is articulated with the interest of both academic and business environments, and that contribute to the debates in the field of social sciences, specifically in the area of economics and business.

Its target audience is professionals, academics, researchers, and students, who seek to update themselves in contents that are related to the thematic areas addressed by this publication.

https://doi.org/10.21158/01208160

\section{Guidelines for authors}

\section{Typology}

The articles that are sent to the School of Business Administration Journal, must be within one of the following categories, taken from the specifications presented by Colciencias -Publindex:

\begin{tabular}{|c|l|}
\hline $\begin{array}{c}\text { Type of article } \\
\begin{array}{c}\text { Article on scientific and technological } \\
\text { investigation }\end{array}\end{array}$ & $\begin{array}{l}\text { Decument that evidences original results of a completed research } \\
\text { project. The structure that is generally used contains four important } \\
\text { sections: introduction, methodology, results, and conclusions. }\end{array}$ \\
\hline Artículo de revisión & $\begin{array}{l}\text { Document resulting from a finished research where the conclusions } \\
\text { of published or unpublished investigations on a field in science or } \\
\text { technology are analyzed, systematized, and integrated, in order to } \\
\text { account for the advances and development trends. It is characterized } \\
\text { by presenting a careful bibliographic review of at least 50 references. }\end{array}$ \\
\hline Reporte de caso & $\begin{array}{l}\text { Document that presents the results of a study on a specific situation, } \\
\text { in order to reveal the technical and methodological experiences } \\
\text { that were considered in a specific case. It should include a review of } \\
\text { literature on similar cases. }\end{array}$ \\
\hline
\end{tabular}




\section{General structure of articles}

Indispensable data that every postulated article must include:

- Full name(s) of the author(s).

- Current institutional affiliation (Academic).

- Email.

- Brief academic biography, specifying only the academic background and the universities where the degrees were obtained.

- $\quad$ ORCID code (Required).

In addition, we suggest for the article to be structured as follows:

- Title.

It should be concise and describe the content of the article clearly and precisely, in such a way that the reader can easily identify the subject.

\section{- Abstract.}

It must be written in Spanish and must have between 200 and 250 words. In the case the article is written in English, French, or Portuguese, the abstract should also be sent in its original language. The abstract is a synthesis of the object of study, the objectives, the methodology, and the most relevant conclusions or findings. It should not include bibliographical references or footnotes.

\section{- Keywords.}

Keywords should include between six and ten items. They must be sent in Spanish.

\section{- Body of the article.}

The body of the article should include the following fundamental elements: introduction, methodology, results, discussion, conclusions, and references.

\section{Article submitting format}

- Format: US Letter $(21.5 \mathrm{~cm} \times 27.9 \mathrm{~cm})$.

- Margins: top $2.5 \mathrm{~cm}$., bottom $2.5 \mathrm{~cm}$., left $2.5 \mathrm{~cm}$., right $2.5 \mathrm{~cm}$.

- Font: Arial.

- Font size: 12 pt.

- Line spacing: 1.5 .

- Columns: 1.

- Processor: Word.

- Length of article: between 17 and 25 pages (not including the reference list) 


\section{Other aspects to be taken into account}

\section{- Citation rules.}

The journal uses an adaptation of the American Psychology Association (APA) as a standard regulation for citation, referencing, and presentation of figures and tables. We strongly suggest the use of the Manual of citation and referencing of the Universidad EAN as a specific guide, available in https://bit.ly/2Pieldx

\section{- Nomenclature of titles and subtitles}

It refers to the numbering of the sections and should be hierarchized in levels that are differentiated by numbers and styles, like this:

Title of the article (capitalized, centered, bold)

\section{Title of the section (Left-justified, bold)}

\subsection{Subtitle first level (Left-justified, indented, bold)}

1.1.1 Subtitle second level. (Left-justified, indented, period)

1.1.1.1 Subtitle third level. (Left-justified, indented, italics, period)

\section{- Figures and tables}

Figure is understood as all that graphic material used in the article -images, photographs, diagrams, etc.--

Table is understood as all the information, statistics, numerical or conceptual comparison, arranged within a box, with rows and columns.

Both the figures and the tables must be numbered consecutively, according to their order of appearance within the text - tables and figures with independent consecutive -; they must have a title that briefly describes their content and the precise reference of the source where it was obtained. The format for this information should be the following:

Figure 1. Sistine Chapel

Source. Gombrich, 1950. (If taken from any source)

Source. Prepared by the author. (If it is created by the author / authors)

Figures and tables must be submitted in gray scale, therefore, it is a must to take into account that the information represented here is sufficiently clear and easy to distinguish.

Besides including them in the body of the text, they must be sent in an additional file in the format in which they were created and in gray scale, not in color. The resolution must be at least $300 \mathrm{dpi}$.

\section{- Footnotes}

The footnotes should only be of a clarifying nature. All data concerning bibliographic references must go in the text body and must be registered in the list of references. 


\section{- References}

All the texts and authors that are mentioned in the body of the text must be registered in the reference list, and all the elements that are registered in the reference list must be included in the body of the text. The sources of figures and tables must also be registered there, in the case they are not prepared by the author.

The reference list is located at the end of the document and should be organized in alphabetical order, by last name. If several publications by the same author have been referenced, they must be organized in chronological order, according to the year of publication. When there are several publications by the same author whose publication date is the same year, they must be differentiated as follows:

López, J. (2018a)

López, J. (2018b)

In the case of articles from scientific and academic journals, it is a requirement to include the DOI, whenever it is available.

In the case of digital sources, URL needs to be provided and verified to make sure it is still in operation.

Here are some examples of the referencing format that should be used:

\section{Articles in periodical publications}

\section{- Digital.}

Martínez, J. (2017). El conocimiento como sistema adaptativo complejo en las organizaciones de gestión de proyectos - PMO. Revista Ontare, 4(2), 27-54. DOI: https://doi.org/10.21158/23823399.v4.n2.2016.1626

Castro-Silva, H.; Diez-Silva, H.; Quijano-Brand, L. (2013). Plan de gestión de costos en dirección de proyectos: aplicación en una empresa del sector minero-industrial de Colombia. Revista Escuela De Administración de Negocios, (74), 22-39. DOI: https://doi.org/10.21158/01208160.n74.2013.734

\section{- Printed.}

Solans, A. (1998). ¿Es el management una ciencia? un programa de diez preguntas para reflexiona. Revista Escuela de Administración de Negocios, (35), 4-20.

Velasco-Duarte, N.; Leguízamo-Vanegas, D. (2017). Arte y educación, un nuevo camino para la formación de públicos en las ferias de arte de América. Comunicación, Cultura Y Política, 7(1), 129-158.

\section{Book:}

\section{- Printed}

Moreno-Monsalve, N. A.; Diez-Silva, H.M. (Eds.) (2018). La gerencia de proyectos como impulsor de la estrategia organizacional. Bogotá: Universidad EAN.

Nagles-García, N.; Gil-Toledo, J. J.; García-Durán, H.; Melo-Melo, C. M.; Vélez-García, R. D.; Reyes-López, O.; Romero-Rincón, J. C. (2018). Innovación y emprendimiento en la educación superior. Bogotá: Universidad EAN. 


\section{- Digital.}

Martínez-Sepúlveda, J. A.; Casallas, M. R. (2018). Contaminación y remediación de suelos en Colombia. Aplicación a la minería de oro. Bogotá: Universidad EAN. Recuperado de http://editorial.universidadean. edu.co/acceso-abierto/contaminacion-y-remediacion-de-suelos-en-colombia.pdf

\section{- Book chapert within a compilation}

Menchero-Sánchez, M. (2017). Ciudades históricas, turismo cultural y cooperación internacional desde un enfoque teórico-conceptual. En C. A. Zambrano-Barrera (Comp.) Cinco miradas al turismo cultural. (15-60). Bogotá: Universidad EAN.

\section{Lesgislation:}

- Ley 1450 de 2011. (16 de junio de 2011). Por la cual se expide el Plan Nacional de Desarrollo, 2010-2014. Diario Oficial, núm. 48102. Congreso de Colombia.

- Decreto 1075 de 2012. (22 de mayo de 2012). Por el cual se reglamenta la organización y funcionamiento de los Órganos Colegiados de Administración y Decisión y las secretarías técnicas, de acuerdo con lo establecido en el artículo $6^{\circ}$ de la Ley número 1530 de 2012. Diario Oficial, núm. 48438. Departamento Nacional de Planeación.

\section{Dissertations:}

Membrado-Corma, C. (2016). Proyecto TIC-TAC, aprendiendo a hacer ciencia (Tesis de maestría). Universitat Jaume I. Castelló de la Plana, España. Recuperado de https://bit.ly/2DMgVRv

\section{Technical documents:}

Departamento Administrativo de Ciencia, Tecnología e Innovación. (18 de diciembre de 2015). Modelo de medición de grupos de investigación, desarrollo tecnológico o de innovación y de reconocimiento de investigadores del sistema nacional de ciencia, tecnología e innovación, año 2015. Bogotá, Colombia. Recuperado de https:// bit.ly/2WYTaxx

\section{Presentation in events:}

Vélez-Álvarez, C.; Giraldo-Zuluaga, L. F. (2018). Evaluación de publicaciones científicas con calidad: una experiencia de una Universidad Pública Colombiana. Ponencia presentada en el 3er Congreso Internacional de Editores Redalyc. Universidad César Vallejo, Trujillo, Perú, 16-18 de mayo.

\section{Press:}

- Printed with author

Schuartz, J. (30 de septiembre de 1993). Obesity affects economic, social status. The Washington Post, A1, A4.

\section{- Printed without author}

Obesity affects economic, social status. (30 de septiembre de 1993). The Washington Post, A1, A4.

\section{- Digital with author}

Cala, P. (01 de mayo de 2019). Si has sido testigo, ¿qué has hecho para transformar tu realidad? El Espectador. Recuperado de https://bit.ly/2H9FrOW 


\section{- Digital without author}

Si has sido testigo, ¿qué has hecho para transformar tu realidad? (01 de mayo de 2019). El Espectador. Recuperado de https://bit.ly/2H9Fr0W

\section{Websites:}

- with date

Universidad EAN. (07 de mayo de 2019). Sector de las TIC en Colombia, un mundo de oportunidades laborales. Recuperado de https://bit.ly/2Vekfuu

\section{- without date}

Universidad EAN. (s.f.). Sector de las TIC en Colombia, un mundo de oportunidades laborales. Recuperado de https://bit.ly/2Vekfuu

\section{Evaluation process}

The articles that are submitted to the Escuela de Administración de Negocios Journal are subject to a complete evaluation process, whose general criteria of selection are the thematic relevance, the scientific quality, the originality, the clarity in the argumentation, and the fulfillment of the parameters of presentation of articles that is established by the journal, in order to guarantee the quality and scientific rigor of the publication. The process in detail is as follows:

Once the thematic axes of the editions of the year and the projection of the editorial calendar have been defined by the Editorial Committee of the journal, we proceed to launch the respective calls, at national and international level, for the reception of articles.

After the closing of the call, the Editorial Committee gets together in order to perform the process of verification of the initial requirements of the articles in DOUBLE BLIND MODALITY; this, in relation to their typology, the compliance with the guidelines for the presentation of articles of the journal, and its thematic focus.

After this first evaluation filter, all the authors receive a notification; and those texts that have passed this first stage continue with the review and evaluation phase in DOUBLE BLIND MODALITY, by external peers.

The selection of external pees is done based on their knowledge and expertise with respect to the subject of the text to be evaluated. This search is done through the database of external collaborators of the publication, which is constantly updated, and the database of arbitrators of Colciencias.

The evaluation is carried out by using the format that has been established by the journal, which is sent to the peers together with the text, the general indications of completion of the format, and the notification of the deadlines that are established for carrying out the review and evaluation.

The two axes around which the evaluation is articulated are the formal structure and the quality of the content, which in turn divide into a series of elements that are rated numerically -from 1 to 5 , with 1 being the lowest value and 5 the highest-, and that in their final sum they give a score that determines the assessment and the concept in front of the publication of the article in the following way: 


\begin{tabular}{|c|c|c|}
\hline SCORE & ASSESSMENT & CONCEPT \\
\hline $100-90$ & EXCELLENT & $\begin{array}{c}\text { Releasable and it does not require adjust- } \\
\text { ments. }\end{array}$ \\
\hline $89-80$ & VERY GOOD & $\begin{array}{c}\text { Releasable if minimum adjustments are } \\
\text { made. }\end{array}$ \\
\hline $79-70$ & GOOD & $\begin{array}{c}\text { Releasable if middle level adjustments are } \\
\text { made. }\end{array}$ \\
\hline $69-60$ & ACCEPTABLE & $\begin{array}{c}\text { Releasable but significant adjustment } \\
\text { must be made. }\end{array}$ \\
\hline $59-0$ & NON ACCEPTABLE & Not releasable \\
\hline
\end{tabular}

According to the concept that is issued by the peer, the author or authors are notified of the observations and suggestions issued during the evaluation, and they also receive the information about the adjustments that are required, if any. In the latter case, a specific deadline for delivery is determined and then the evaluating peers carry out a verification process of these adjustments.

In case of controversy of any kind, it is the editor together with the Editorial Committee, the body that makes decisions on the situation and delivers final verdict in this regard.

\section{Estimated time for evaluation}

In order to guarantee a correct and rigorous evaluation process in each of its phases, the verdicts are estimated to be delivered in the following average times:

- First phase - Editorial Committee: given that this phase is carried out at the end of the call period, once the total of articles participating in the editorial process have been compiled and that the meetings are scheduled by coordinating the agendas of its members according to the their time availability, the average response time is approximately 3 months.

- Second phase - External peers: taking into account the time that external peers take to accept the invitations and their availability to carry out the readings, it is estimated that the average time for the verdict in this phase is 3 months, approximately.

\section{About copyright}

The articles that are postulated for publication must be original and unpublished and may not have any editorial commitment for publication, nor should they be in the process of simultaneous evaluation by another publication or entity.

In the case of using photographs or images, publication permits must be sent along with the article.

The author or authors must authorize the publication of their text by means of the completion and signature of the "Authorization for publication in favor of the EAN University" format. The publisher provides this format once the article has satisfactorily passed the two stages of evaluation and has been approved for publication.

The authors of articles that are published in the journal will be entitled to receive two physical copies of the same number in which their contribution appeared.

In any case, the Scientific and Editorial Committee of the journal understands and declares that the opinions that are expressed by the authors are their sole responsibility. 


\section{Frequency}

The School of Business Administration Journal is a semi-annual publication, which publishes its editions as follows:

- January to June.

- July to December.

\section{Open access policy}

The School of Business Administration Journal provides free and permanent access to its contents, based on the principle of global exchange of knowledge. In this same sense, the publication does not require any type of payment or compensation, neither for the application, nor the evaluation, or the publication of articles.

The content of the journal is under a Creative Commons Attribution-NonCommercial-NoDerivative 4.0 International license.

The School of Business Administration Journal allows self-archiving published articles by their own authors, in thematic repositories or personal web pages, once the final PDF version is published on our platform. The selfarchiving or publication of the manuscripts, or the versions prior to the layout of the texts, are not authorized.

\section{Policy for the preservation of digital archives}

The preservation of digital archives of the journal is carried out through LOCKSS and CLOKSS.

\section{Indexing}

Currently, the journal is indexed in the Directory of Open Access Journals (DOAJ), the Scientific Electronic Library Online (SciELO), the Network of scientific journals in Latin America and the Caribbean (Redalyc by its abbreviation in Spanish), the Ibero-American Network of innovation and scientific knowledge (REDIB by its abbreviation in Spanish), EBSCOhost, EconLit, and in the national index Publindex of Colciencias in category B.

\section{History of the journal}

In 1986, the School of Business Administration Journal was created as an institutional initiative for the dissemination of knowledge that arose from the scientific work of its teachers and researchers. From then until today, the publication has gone through several stages of change, which have involved, among other elements: the definition of the social sciences as its academic field of action, and of the economy and business as a specific thematic area; the opening of its space to professors and researchers of different institutions, and the entrance to the world of digital publications. 


\section{Pautas para publicar na Revista EAN}

\section{Enfoque e alcance}

A Revista Escuela de Administración de Negocios é uma publicação de caráter científico e acadêmico, editada semestralmente pela Universidad EAN. Seu objetivo principal é a publicação de trabalhos resultados de pesquisa que se articulem com o interesse tanto do meio acadêmico como do empresarial, e que contribuam nos debates no campo das ciências sociais, especificamente na área da economia e dos negócios.

Seu público alvo são os profissionais, acadêmicos, pesquisadores e estudantes, que procuram se atualizar em conteúdos relacionados com os eixos temáticos que aborda a publicação.

https://doi.org/10.21158/01208160

\section{Pautas para autores}

\section{Tipologia}

Os artigos que forem enviados à Revista Escuela de Administración de Negocios, devem estar dentro de uma das seguintes categorias, tomadas das especificações apresentadas por Colciencias -Publindex:

\begin{tabular}{|c|l|}
\hline Tipo de artigo & \multicolumn{1}{c|}{ Descrição } \\
\hline $\begin{array}{c}\text { Artigo de pesquisa científica e } \\
\text { tecnológica }\end{array}$ & $\begin{array}{l}\text { Documento que evidencia resultados originais de um projeto de } \\
\text { pesquisa concluído. A estrutura geralmente utilizada contém quatro } \\
\text { partes importantes: introdução, metodologia, resultados e conclusões. }\end{array}$ \\
\hline $\begin{array}{l}\text { Artigo de revisão } \\
\text { Documento resultado de uma pesquisa terminada onde se analisam, } \\
\text { sistematizam e integram os resultados de pesquisas publicadas ou } \\
\text { não publicadas, sobre um campo em ciência ou tecnologia, com o } \\
\text { fim de dar conta dos avanços e das tendências de desenvolvimento. } \\
\text { Caracteriza-se por apresentar uma cuidadosa revisão bibliográfica de } \\
\text { pelo menos 50 referências. }\end{array}$ \\
\hline Reporte de caso & $\begin{array}{l}\text { Documento que apresenta os resultados de um estudo sobre uma } \\
\text { situação pontual, para dar a conhecer as experiências técnicas e } \\
\text { metodológicas conceituadas em um caso específico. Deve incluir uma } \\
\text { revisão de literatura sobre casos análogos. }\end{array}$ \\
\hline
\end{tabular}




\section{Estrutura geral dos artigos}

Os dados indispensáveis dos artigos postulados são:

- Nome(s) completo(s) do autor(es).

- Filiação institucional atual (acadêmica).

- E-mail.

- Breve biografia acadêmica, na que se especifiquem títulos acadêmicos e universidades onde foram obtidos.

- Código ORCID (obrigatório).

Além disso, sugere-se que o artigo se estruture da seguinte maneira:

\section{- Título.}

Deve ser conciso e descrever o conteúdo do artigo deforma clara e precisa, de tal maneira que o leitor identifique o tema facilmente.

\section{- Resumo.}

Deve ser em espanhol e deve ter entre 200 e 250 palavras. Caso o artigo esteja escrito em inglês, francês ou português, também deve ser remetido o resumo em seu idioma original. Trata-se de uma síntese do objeto de estudo, os objetivos, a metodologia e as conclusões ou resultados mais relevantes. Não deve incluir referências bibliográficas nem notas de pé de página.

- Palavras-chave.

Devem oscilar entre os seis e dez itens. Devem ser remetidas em espanhol.

\section{- Corpo do artigo.}

Como elementos fundamentais deve conter: introdução, metodologia, resultados, discussão, conclusões e referências.

\section{Formato de apresentação dos artigos}

- Formato: carta $(21.5 \mathrm{~cm} \times 27.9 \mathrm{~cm})$.

- Margens: Sup. $2.5 \mathrm{~cm}$. Inf. $2.5 \mathrm{~cm}$. Esq. $2.5 \mathrm{~cm}$. Dir. $2.5 \mathrm{~cm}$.

- Fonte: Arial.

- Tamanho de fonte: 12 pontos.

- Entrelinha: 1.5.

- Colunas: 1.

- Processador: Word.

- Extensão do artigo: entre 17 e 25 páginas (sem contar lista de referências) 


\section{Outros aspectos a ter em conta}

\section{- Normas de citações}

A revista emprega uma adaptação da American Psychology Association (APA) como norma no tocante a citações, referências e apresentação de figuras e tabelas. Sugere-se utilizar como guia específica o Manual de citações e referências da universidade EAN, disponível em https://bit.ly/2Pieldx

\section{- Nomenclatura de títulos e subtítulos}

Refere-se à numeração das partes e vai hierarquizada em níveis diferenciados por números e estilos assim:

\section{Título do artigo (maiúscula inicial, centrado e em negrito)}

\section{Título de partes (justificado à esquerda em negrito)}

\subsection{Subtítulo primeiro nível (justificado à esquerda, com sangria, em negrito)}

1.1.1 Subtítulo segundo nível. (justificado à esquerda, com sangria, com ponto ao final)

1.1.1.1 Subtítulo terceiro nível. (justificado à esquerda, com sangria, em itálico e com ponto ao final)

\section{- Figuras e tabelas}

Se entende como figura todo aquele material gráfico utilizado no artigo — imagens, fotografias, diagramas etc.- . Entende-se como tabela, toda a informação, estatística, numérica ou de comparação conceitual, disposta dentro de uma caixa, com linhas e colunas.

Tanto as figuras como as tabelas devem ser numeradas de forma consecutiva, segundo sua ordem de aparecimento dentro do texto - tabelas e figuras com consecutivo independente-; devem ter um título que descreva brevemente seu conteúdo e a referência precisa da fonte de onde foi obtida. $O$ formato para esta informação deve ser o seguinte:

Figura 1. Capela Sistina

Fonte. Gombrich, 1950. (Se é tomada de alguma fonte)

Fonte. Elaboração própria. (Se é criação do autor/autores)

Figuras e tabelas devem ser remetidas em escala de cinzas, por isso deve-se considerar que a informação ali representada seja suficientemente clara e fácil de distinguir.

Além de apresentar no corpo do texto, devem ser enviadas em um arquivo adicional no formato de origem no que foram criados e em escala de cinzas, não coloridas. A resolução deve ser de 300dpi como mínimo.

\section{- Notas a pé de página}

As notas de pé de página devem ser unicamente de caráter esclarecedor. Todos os dados concernentes a referências bibliográficas devem ir dentro do corpo de texto e registrados na lista de referências. 


\section{- Referências}

Todos os textos e autores que se mencionarem no corpo do texto deverão ser registrados na lista de referências e todos os elementos que estiverem registrados na lista de referências deverão estar incluídos no corpo do texto. As fontes de figuras e tabelas também devem ser registradas ali, caso não sejam de elaboração própria.

A lista de referências se localiza ao final do documento e deve organizar-se em ordem alfabética, segundo o sobrenome. Caso devam ser referidas várias publicações do mesmo autor, estas devem ir organizadas em ordem cronológica, segundo ano de publicação. Quando existirem várias produções de um mesmo autor cuja data de publicação for o mesmo ano, devem ser diferenciadas da seguinte maneira:

López, J. (2018a)

López, J. (2018b)

Para o caso de artigos de revistas científicas e académicas solicita-se incluir o DOI, quando este se encontre disponível.

Para o caso de fontes digitais solicita-se proporcionar a URL e verificar que a mesma se encontre em funcionamento.

A seguir, apresentam-se alguns exemplos do formato de referência que deve ser utilizados:

\section{Artigos em publicações periódicas:}

\section{- Digitais.}

Martínez, J. (2017). El conocimiento como sistema adaptativo complejo en las organizaciones de gestión de proyectos - PMO. Revista Ontare, 4(2), 27-54. DOI: https://doi.org/10.21158/23823399.v4.n2.2016.1626

Castro-Silva, H.; Diez-Silva, H.; Quijano-Brand, L. (2013). Plan de gestión de costos en dirección de proyectos: aplicación en una empresa del sector minero-industrial de Colombia. Revista Escuela De Administración de Negocios, (74), 22-39. DOI: https://doi.org/10.21158/01208160.n74.2013.734

\section{- Impressas.}

Solans, A. (1998). ¿Es el management una ciencia? un programa de diez preguntas para reflexiona. Revista Escuela de Administración de Negocios, (35), 4-20.

Velasco-Duarte, N.; Leguízamo-Vanegas, D. (2017). Arte y educación, un nuevo camino para la formación de públicos en las ferias de arte de América. Comunicación, Cultura Y Política, 7(1), 129-158.

\section{Livros:}

\section{- Impressos}

Moreno-Monsalve, N. A.; Diez-Silva, H.M. (Eds.) (2018). La gerencia de proyectos como impulsor de la estrategia organizacional. Bogotá: Universidad EAN.

Nagles-García, N.; Gil-Toledo, J.J.; García-Durán, H.; Melo-Melo, C. M.; Vélez-García, R. D.; Reyes-López, O.; Romero-Rincón, J. C. (2018). Innovación y emprendimiento en la educación superior. Bogotá: Universidad EAN. 


\section{- Digitais.}

Martínez-Sepúlveda, J. A.; Casallas, M. R. (2018). Contaminación y remediación de suelos en Colombia. Aplicación a la minería de oro. Bogotá: Universidad EAN. Recuperado de http://editorial.universidadean. edu.co/acceso-abierto/contaminacion-y-remediacion-de-suelos-en-colombia.pdf

\section{- Capítulo de livro desntro de compilação}

Menchero-Sánchez, M. (2017). Ciudades históricas, turismo cultural y cooperación internacional desde un enfoque teórico-conceptual. En C. A. Zambrano-Barrera (Comp.) Cinco miradas al turismo cultural. (15-60). Bogotá: Universidad EAN.

\section{Legislação::}

- Ley 1450 de 2011. (16 de junio de 2011). Por la cual se expide el Plan Nacional de Desarrollo, 2010-2014. Diario Oficial, núm. 48102. Congreso de Colombia.

- Decreto 1075 de 2012. (22 de mayo de 2012). Por el cual se reglamenta la organización y funcionamiento de los Órganos Colegiados de Administración y Decisión y las secretarías técnicas, de acuerdo con lo establecido en el artículo $6^{\circ}$ de la Ley número 1530 de 2012. Diario Oficial, núm. 48438. Departamento Nacional de Planeación.

Tese:

Membrado-Corma, C. (2016). Proyecto TIC-TAC, aprendiendo a hacer ciencia (Tesis de maestría). Universitat Jaume I. Castelló de la Plana, España. Recuperado de https://bit.ly/2DMgVRv

\section{Documentos técnicos:}

Departamento Administrativo de Ciencia, Tecnología e Innovación. (18 de diciembre de 2015). Modelo de medición de grupos de investigación, desarrollo tecnológico o de innovación y de reconocimiento de investigadores del sistema nacional de ciencia, tecnología e innovación, año 2015. Bogotá, Colombia. Recuperado de https://bit. ly/2WYTaxx

\section{Conferências em eventos:}

Vélez-Álvarez, C.; Giraldo-Zuluaga, L. F. (2018). Evaluación de publicaciones científicas con calidad: una experiencia de una Universidad Pública Colombiana. Ponencia presentada en el 3er Congreso Internacional de Editores Redalyc. Universidad César Vallejo, Trujillo, Perú, 16-18 de mayo.

\section{Impressas:}

- Impresso con autor

Schuartz, J. (30 de septiembre de 1993). Obesity affects economic, social status. The Washington Post, A1, A4.

\section{- Impreso sem autor}

Obesity affects economic, social status. (30 de septiembre de 1993). The Washington Post, A1, A4.

\section{- Digital com autor}

Cala, P. (01 de mayo de 2019). Si has sido testigo, ¿qué has hecho para transformar tu realidad? El Espectador. Recuperado de https://bit.ly/2H9FrOW 


\section{- Digital sem autor}

Si has sido testigo, ¿qué has hecho para transformar tu realidad? (01 de mayo de 2019). El Espectador. Recuperado de https://bit.ly/2H9FrOW

\section{Páginas de internet:}

\section{- Com data conhecida}

Universidad EAN. (07 de mayo de 2019). Sector de las TIC en Colombia, un mundo de oportunidades laborales. Recuperado de https://bit.ly/2Vekfuu

\section{- Com desconhecida}

Universidad EAN. (s.f.). Sector de las TIC en Colombia, un mundo de oportunidades laborales. Recuperado de https://bit.ly/2Vekfuu

\section{Processo de avaliação}

Os artigos postulados à Revista Escuela de Administración de Negocios são submetidos a um completo processo de avaliação, que tem como critérios gerais de seleção a pertinência temática, a qualidade científica, a originalidade, a clareza na argumentação e o cumprimento dos parâmetros de apresentação de artigos estabelecidos pela revista, com o fim de garantir a qualidade e o rigor científico da publicação. A seguir, descrevemos com detalhe este processo.

Uma vez definidos tanto os eixos temáticos das edições do ano como a projeção do calendário editorial por parte do Comitê Editorial da revista procedem-se a lançar os respectivos editais, de alcance nacional e internacional, para recepção de artigos.

Depois do fechamento do edital, o Comitê Editorial reúne-se para realizar em MODALIDADE DE AVALIADOR OCULTO o processo de verificação de requisitos iniciais dos artigos, com relação a sua tipologia, o cumprimento das pautas de apresentação de artigos da revista e o foco temático deste.

Depois deste primeiro filtro de avaliação, realiza-se a respectiva notificação à totalidade dos autores e aqueles textos que superarem esta primeira etapa, continuam com a fase de revisão e avaliação em MODALIDADE DE AVALIADOR OCULTO, por parte de externos.

A seleção dos avaliadores externos realiza-se em função de seu conhecimento e perícia com respeito à temática do texto a avaliar. Esta busca realiza-se através do banco de dados de colaboradores externos da publicação - que se encontra em constante atualização - e do banco de dados de árbitros de Colciencias.

A avaliação realiza-se através do formulário estabelecido pela revista, que se envia aos avaliadores do texto, pelas indicações gerais de preenchimento e pela notificação dos prazos estabelecidos para realizar a respectiva revisão e avaliação.

Os dois eixos ao redor dos quais se articula a avaliação são a estrutura formal e a qualidade do conteúdo, os quais de dividem por sua vez em uma série de elementos que se avaliam de forma numérica - de 1 a 5 , sendo 1 o menor valor e 5 o maior -, e que em sua soma final geram uma pontuação que determina a avaliação e o conceito frente à publicação do artigo da seguinte maneira: 


\begin{tabular}{|c|c|c|}
\hline QUALIFICAÇÃO & VALORAÇÃO & CONCEITO \\
\hline $100-90$ & EXCELENTE & Publicável e não requer ajustes. \\
\hline $89-80$ & MUITO BOM & Publicável com ajustes mínimos. \\
\hline $79-70$ & BOM & Publicável com ajustes nível médio. \\
\hline $69-60$ & ACEITÁVEL & Publicável com ajustes significativos. \\
\hline $59-0$ & NÃO ACEITÁVEL & Não é publicável. \\
\hline
\end{tabular}

De acordo com o conceito emitido pelo avaliador, procede-se a realizar a notificação ao autor ou autores, com a respectiva retroalimentação das observações e sugestões emitidas mediante a avaliação e a solicitação de ajustes, caso sejam necessárias. Neste último caso, determina-se um prazo específico de entrega e posteriormente realizase um processo de verificação destes ajustes, sob a responsabilidade dos avaliadores.

Em caso de apresentar-se controvérsia de qualquer tipo, é o editor, em conjunto com o comitê editorial, a instância que dirime a situação e entrega veredito final a respeito.

\section{Tempo estimado para a avaliação}

Com o objetivo de garantir um correto e rigoroso processo de avaliação em cada uma de suas fases, estimam-se os seguintes tempos em média para a entrega de vereditos.

- Primeira fase - Comitê editorial: esta fase se realiza com o término do período de apresentação de artigos, com a confirmação do total de artigos participantes no processo editorial, com a programação das reuniões de seus membros de acordo a seu tempo disponível. Seu tempo médio de resposta é de 3 meses, aproximadamente.

- Segunda fase - Avaliadores externos: tendo em conta os tempos de aceitação aos convites realizados a avaliadores e a disponibilidade dos mesmos para realizar as leituras, estima-se que o tempo médio nesta fase seja de 3 meses, aproximadamente.

\section{Sobre os direitos de autor}

Os artigos postulados deverão ser originais e inéditos e não poderão ter nenhum compromisso editorial de publicação, nem devem ser encontrados em processo de avaliação simultâneo por parte de outra publicação ou entidade.

No caso de usar fotografia ou imagens, devem ser enviadas as respectivas permissões de uso e publicação destas. $\mathrm{O}$ autor ou autores, deverão autorizar a publicação de seu texto através do preenchimento e assinatura do formulário de "Autorização da publicação em favor da Universidade EAN". Este formulário é fornecido pela editora uma vez o artigo supere satisfatoriamente as duas etapas de avaliação e seja aprovado para publicação.

Os autores dos artigos que se publiquem na revista, terão direito a receber duas exemplares físicos do mesmo número no que apareceu seu texto.

Em qualquer caso, o Comité Científico e Editorial da revista entende e declara que as opiniões expostas pelos autores, são de exclusiva responsabilidade destes. 


\section{Frequência}

A Revista Escuela de Administración de Negocios é uma publicação de frequência semestral, que publica suas edições da seguinte maneira:

- Janeiro a junho.

- Julio a dezembro.

\section{Política de acesso aberto}

A Revista Escuela de Administración de Negocios proporciona acesso livre e permanente a seus conteúdos, baseada no princípio de intercâmbio global do conhecimento. Neste mesmo sentido, a publicação não exige nenhum tipo de pagamento nem compensação, nem pela postulação, nem pela avaliação, nem pela publicação de artigos. O conteúdo da revista está sob uma licença de Creative Commons Reconocimiento-NoComercialSinObraDerivada 4.0 Internacional.

A Revista Escuela de Administración de Negocios permite o autoarquivo por parte dos autores de seus artigos publicados, em repositórios temáticos ou páginas web pessoais, uma vez que se encontre a versão final em PDF publicada em nossa plataforma. Não se autoriza o autoarquivo ou publicação dos manuscritos, nem das versões prévias à diagramação dos textos.

\section{Política de preservação de arquivos digitais}

A preservação de arquivos digitais da revista realiza-se através de LOCKSS e CLOKSS.

\section{Indexação}

Atualmente, a revista se encontra indexada em DOAJ (Directory of Open Access Journals), SciELO (Scientific Electronic Library On-line), Redalyc (Rede de revistas científicas de América Latina e o Caraíbas), REDIB (Rede Iberoamericana de inovação e conhecimento científico), EBSCOhost, EconLit, e no índice nacional Publindex de Colciencias na categoria B.

\section{História da revista}

No ano de 1986 nasce a Revista Escuela de Administración de Negocios, como uma iniciativa institucional para a difusão do conhecimento que surgia do trabalho científico de seus docentes e pesquisadores. Desde então até hoje, a publicação tem atravessado várias etapas de mudança, que têm envolvido entre outros elementos: a definição das ciências sociais como seu campo acadêmico de ação e da economia e dos negócios como área temática específica; a abertura de seu espaço a professores e pesquisadores de distintas instituições e a entrada ao mundo das publicações digitais. 


\section{Règles et normes de publication de la Revue EAN}

\section{Approche et portée}

La Revue Escuela de Administración de Negocios est une publication scientifique et académique biannuelle publiée par l'Université EAN. Son objectif principal est la publication d'ouvrages issus de recherches réalisées dans le domaine des sciences sociales, de l'économie et de la gestion s'ajustant aux centres d'intérêt des milieux académiques et des entreprises contribuant aux débats.

Son public cible est constitué de professionnels, d'universitaires, de chercheurs et d'étudiants souhaitant actualiser leurs connaissances dans les domaines thématiques abordés dans la publication.

\section{Lignes directrices pour les auteurs}

\section{Typologie}

Les articles envoyés à la Revue Escuela de dministración de Negocios doivent appartenir à l'une des catégories extraites des spécifications recommandées par Colciencias - Publindex.

\begin{tabular}{|c|l|}
\hline Elément type & \multicolumn{1}{c|}{ Description } \\
\hline $\begin{array}{c}\text { Article de recherche scientifique et } \\
\text { technologique }\end{array}$ & $\begin{array}{l}\text { Document attestant des résultats originaux d'un projet de } \\
\text { recherche achevé. La structure utilisée comprend quatre sections : } \\
\text { introduction, méthodologie, résultats et conclusions. }\end{array}$ \\
\hline Article de revue & $\begin{array}{l}\text { Documenter une recherche finalisée dans laquelle les résultats } \\
\text { sont publiés, analysés, systématisés et intégrés dans un domaine } \\
\text { scientifique ou technologique afin de rendre compte des progrès et } \\
\text { des tendances du développement. Larticle donne une bibliographie } \\
\text { minutieuse d'au moins 50 références. }\end{array}$ \\
\hline Rapport de cas & $\begin{array}{l}\text { Document présentant les résultats d'une étude sur une } \\
\text { situation spécifique et analysant les expériences techniques et } \\
\text { méthodologiques retenues dans ce cas particulier. Le document doit } \\
\text { inclure une bibliographie de cas similaires. }\end{array}$ \\
\hline
\end{tabular}




\section{Structure générale des articles}

Les données indispensables que chaque article postulé doit inclure sont :

- Nom complet de l'auteur.

- Affiliation institutionnelle actuelle.

- Courrier électronique.

- Brève biographie académique dans laquelle les diplômes universitaires seront indiqués.

- Code ORCID.

\section{Il est suggéré de structurer l’article de la manière suivante :}

- Titre.

Il doit être concis et décrire le contenu de l'article de manière claire et précise pour que le lecteur puisse facilement identifier le sujet.

- Résumé.

Il doit être rédigé en espagnol et comporter entre 200 et 250 mots. Si l'article est rédigé en anglais, en français ou en portugais, le résumé doit également être envoyé dans sa langue d'origine. Il s'agit d'une synthèse de l'objet d'étude, des objectifs, de la méthodologie et des conclusions ou résultats les plus pertinents. Il ne doit pas inclure de références bibliographiques ou de notes de bas de page.

- Mots-clés.

Il s'agit de six à dix mots-clés devant être envoyés en espagnol.

\section{- Corps de l'article.}

Il doit contenir les éléments suivant: introduction, méthodologie, résultats, discussion, conclusions et références.

\section{Format de présentation des articles}

- Format : A4 - lettre $(21,5 \mathrm{~cm} \times 27,9 \mathrm{~cm})$.

- Marges : Sup 2,5 cm / Inf 2,5 cm / Gauche 2,5 cm / Droite 2,5 cm

- Police : Arial

- Taille de la police : 12 points.

- Interligne : 1.5

- Colonnes : 1

- Processeur : Word.

- Longueur de l’article : de 17 à 25 pages (plus liste des références) 


\section{Autres aspects à prendre en compte :}

\section{- Règles de citation:}

La revue utilise une adaptation de l'American Psychology Association (APA) pour les citations, le référencement et la présentation des graphiques et tableaux. Il est suggéré d'utiliser le manuel de citation et de référencement de l'université EAN, disponible à l'adresse https://bit.ly/2Pieldx.

\section{- Nomenclature des titres et sous-titres}

Il s’agit de la numérotation des parties, hiérarchisées et différenciées :

\section{Titre de l'article (Centré, en majuscule et en gras)}

\section{Titre de la section (Justifié à gauche en gras)}

\subsection{Sous-titre premier niveau (Justifié à gauche, en retrait, en gras)}

1.1.1 Sous-titre deuxième niveau. (Justifié à gauche, avec point final)

1.1.1.1 Sous-titre troisième niveau. (Justifié à gauche, en italique avec point final)

\section{- Graphiques et tableaux}

On entend par figure tout matériel graphique utilisé dans l'article —images, photographies, diagrammes, etc.—. On entend par tableau, toutes les informations, statistiques, numériques ou de comparaison conceptuelle, disposées dans un cadre, avec des lignes et des colonnes.

Les graphiques et les tableaux doivent être numérotés de manière consécutive, en fonction de leur ordre d'apparition dans le texte - tableaux et graphiques à caractères indépendants et consécutifs, qui doivent avoir un titre décrivant brièvement leur contenu et la référence précise de la source. Le format de cette information doit être le suivant:

Figure 1. Chapelle Sixtine

Source Gombrich, 1950 (si tiré d'une source quelconque)

Source Élaboration propre (s'il s'agit d'une création de l'auteur / des auteurs)

Les graphiques et tableaux doivent être présentés en dégradés de gris en prenant compte le fait que les informations présentées doivent être suffisamment claires et faciles à distinguer.

Tableaux et graphiques doivent se situer dans le corps du texte et être envoyés en fichier annexe au format d'origine et en dégradé de gris, pas en couleur. La résolution doit être d’au moins 300 dpi.

\section{- Notes de bas de page}

Les notes de bas de page doivent être insérées uniquement à titre de clarification. Toutes les données concernant les références bibliographiques doivent figurer dans le corps du texte et être annotées dans la liste des références bibliographiques. 


\section{- Référencement}

Tous les textes et auteurs mentionnés dans le corps du texte doivent être inscrits dans la liste de références et tous les éléments inscrits dans la liste de références doivent être inclus dans le corps du texte. Les sources des graphiques et tableaux doivent également y être enregistrées.

La liste des références est située en fin de document et organisée par ordre alphabétique, par nom de famille. Si plusieurs publications du même auteur sont référencées, elles devront être organisées par ordre chronologique, en fonction de l'année de publication. Lorsqu'il y a plusieurs publications du même auteur dont la date de publication est de la même année, elles devront être différenciées comme suit :

López, J. (2018a)

López, J. (2018b)

Dans le cas d’articles de revues scientifiques et académiques, il est demandé d'inclure si possible le DOI.

Pour les sources numériques, fournir l'URL et vérifier son fonctionnement.

Voici des exemples du format de référencement à utiliser :

\section{Articles de publications périodiques:}

\section{- Numérique.}

Martínez, J. (2017). El conocimiento como sistema adaptativo complejo en las organizaciones de gestión de proyectos - PMO. Revista Ontare, 4(2), 27-54. DOI: https://doi.org/10.21158/23823399.v4.n2.2016.1626

Castro-Silva, H.; Diez-Silva, H.; Quijano-Brand, L. (2013). Plan de gestión de costos en dirección de proyectos: aplicación en una empresa del sector minero-industrial de Colombia. Revista Escuela De Administración de Negocios, (74), 22-39. DOI: https://doi.org/10.21158/01208160.n74.2013.734

\section{- Imprimé.}

Solans, A. (1998). ¿Es el management una ciencia? un programa de diez preguntas para reflexiona. Revista Escuela de Administración de Negocios, (35), 4-20.

Velasco-Duarte, N.; Leguízamo-Vanegas, D. (2017). Arte y educación, un nuevo camino para la formación de públicos en las ferias de arte de América. Comunicación, Cultura Y Política, 7(1), 129-158.

\section{Livres:}

- Imprimé

Moreno-Monsalve, N. A.; Diez-Silva, H.M. (Eds.) (2018). La gerencia de proyectos como impulsor de la estrategia organizacional. Bogotá: Universidad EAN.

Nagles-García, N.; Gil-Toledo, J.J.; García-Durán, H.; Melo-Melo, C. M.; Vélez-García, R. D.; Reyes-López, O.; Romero-Rincón, J. C. (2018). Innovación y emprendimiento en la educación superior. Bogotá: Universidad EAN. 


\section{- Numérique.}

Martínez-Sepúlveda, J. A.; Casallas, M. R. (2018). Contaminación y remediación de suelos en Colombia. Aplicación a la minería de oro. Bogotá: Universidad EAN. Recuperado de http://editorial.universidadean. edu.co/acceso-abierto/contaminacion-y-remediacion-de-suelos-en-colombia.pdf

\section{- Chapitre de libre en compilation}

Menchero-Sánchez, M. (2017). Ciudades históricas, turismo cultural y cooperación internacional desde un enfoque teórico-conceptual. En C. A. Zambrano-Barrera (Comp.) Cinco miradas al turismo cultural. (15-60). Bogotá: Universidad EAN.

\section{Législation: :}

- Ley 1450 de 2011. (16 de junio de 2011). Por la cual se expide el Plan Nacional de Desarrollo, 2010-2014. Diario Oficial, núm. 48102. Congreso de Colombia.

- Decreto 1075 de 2012. (22 de mayo de 2012). Por el cual se reglamenta la organización y funcionamiento de los Órganos Colegiados de Administración y Decisión y las secretarías técnicas, de acuerdo con lo establecido en el artículo $6^{\circ}$ de la Ley número 1530 de 2012. Diario Oficial, núm. 48438. Departamento Nacional de Planeación.

\section{thése:}

Membrado-Corma, C. (2016). Proyecto TIC-TAC, aprendiendo a hacer ciencia (Tesis de maestría). Universitat Jaume I. Castelló de la Plana, España. Recuperado de https://bit.ly/2DMgVRv

\section{Documents techniques:}

Departamento Administrativo de Ciencia, Tecnología e Innovación. (18 de diciembre de 2015). Modelo de medición de grupos de investigación, desarrollo tecnológico o de innovación y de reconocimiento de investigadores del sistema nacional de ciencia, tecnología e innovación, año 2015. Bogotá, Colombia. Recuperado de https://bit. ly/2WYTaxx

\section{Présentations lors d'événements}

Vélez-Álvarez, C.; Giraldo-Zuluaga, L. F. (2018). Evaluación de publicaciones científicas con calidad: una experiencia de una Universidad Pública Colombiana. Ponencia presentada en el 3er Congreso Internacional de Editores Redalyc. Universidad César Vallejo, Trujillo, Perú, 16-18 de mayo.

\section{Presse:}

- Écrite avec auteur Schuartz, J. (30 de septiembre de 1993). Obesity affects economic, social status. The Washington Post, A1, A4.

- Écrite sans auteur Obesity affects economic, social status. (30 de septiembre de 1993). The Washington Post, A1, A4.

\section{- Numérique avec autor}

Cala, P. (01 de mayo de 2019). Si has sido testigo, ¿qué has hecho para transformar tu realidad? El Espectador. Recuperado de https://bit.ly/2H9Fr0W 


\section{- Númerique sans auteur}

Si has sido testigo, ¿qué has hecho para transformar tu realidad? (01 de mayo de 2019). El Espectador. Recuperado de https://bit.ly/2H9Fr0W

\section{Pages internet:}

\section{- Data connue}

Universidad EAN. (07 de mayo de 2019). Sector de las TIC en Colombia, un mundo de oportunidades laborales. Recuperado de https://bit.ly/2Vekfuu

\section{- Data inconnue}

Universidad EAN. (s.f.). Sector de las TIC en Colombia, un mundo de oportunidades laborales. Recuperado de https://bit.ly/2Vekfuu

\section{Processus d'évaluation}

Les articles soumis à la Revue Escuela de Administración de Negocios sont soumis à un processus d'évaluation complet ayant comme critères de sélection la pertinence thématique, la qualité scientifique, l'originalité, la clarté de l'argumentation et le respect des paramètres de présentation des articles établis par la revue afin de garantir la qualité et la rigueur scientifique de la publication. Nous décrirons ce processus en détail.

Une fois les axes thématiques mis en place, les dates d'éditions sont lancées simultanément au calendrier éditorial pour que le comité de rédaction de la revue lance les appels respectifs de portée nationale et internationale pour la réception d'articles.

Après la clôture de l’appel à participation, le comité de rédaction se réunit pour mener à bien le processus de vérification des exigences initiales des articles, en MODE DOUBLE AVEUGLE, pour vérifier la typologie, le respect des directives de présentation des articles et les priorités thématiques de celle-ci.

Après ce premier filtre d'évaluation, une notification est adressée à tous les auteurs des textes ayant réussi cette première étape de sélection avec les dates des phases de révision et d'évaluation se poursuivant, toujours en MODE DOUBLE AVEUGLE, et réalisées par des pairs externes.

La sélection de ces pairs externes est effectuée en fonction de leurs connaissances et de leur expertise dans le domaine du texte à évaluer. Cette recherche est effectuée grâce à la base de données des collaborateurs externes à la publication, constamment mise à jour, et à la base de données des pairs de Colciencias.

L'évaluation est effectuée en utilisant le format établi par la revue qui sera envoyé aux pairs avec le texte, les indications générales d'évaluation et la notification des délais impartis pour la réalisation de l'examen et de l'évaluation.

Les deux axes autour desquels lévaluation est articulée sont la structure formelle et la qualité du contenu, qui se divise à leur tour en une série d'éléments notés numériquement de 1 à 5 , 1 étant la valeur la plus basse et 5 la plus élevée - pour que lors du calcul de la note finale soit attribué un score déterminant l'évaluation et le concept de la publication de l'article de la manière suivante: 


\begin{tabular}{|c|c|c|}
\hline NOTE & ÉVALUATION & CONCEPT \\
\hline $100-90$ & EXCELLENT & Publiable, ne nécessitant aucun ajustement. \\
\hline $89-80$ & TRÈS BON & Publiable, nécessitant des ajustements minimes. \\
\hline $79-70$ & BON & Publiable, nécessitant des ajustements moyens. \\
\hline $69-60$ & ACCEPTABLE & Publication différée, nécessitant des ajustements importants. \\
\hline $59-0$ & NON ACCEPTABLE & Non publiable. \\
\hline
\end{tabular}

En fonction du concept émis par les pairs, la notification est adressée à ou aux auteurs avec le retour d'informations respectif des observations et suggestions émises lors de l'évaluation et la demande d'ajustements, si nécessaire. Dans ce dernier cas, un délai pour la remise de l’article corrigé est déterminé puis un processus de vérification de ces ajustements est effectué par les pairs évaluateurs.

En cas de controverse ou désaccords, l'éditeur et le comité de rédaction prendront la décision finale et rendront leur verdict.

\section{Temps estimé pour l'évaluation}

Afin de garantir un processus d'évaluation correct et rigoureux lors de chacune de phases précédentes, les délais de remise suivants devront être respectés :

- Première phase - Comité de rédaction : étant donné que cette étape est réalisée à la fin de la période d’appel, une fois réunis le nombre total d'articles participant au processus éditorial et les réunions programmées en coordonnant les ordres du jour de ses membres conformément à leur disponibilité, le temps de réponse moyen est de 3 mois environ.

- Deuxième phase - Pairs externes : compte tenu des heures d'acceptation des invitations faites aux pairs externes et de leur disponibilité à effectuer les lectures, la durée moyenne du verdict de cette phase est de 3 mois environ.

\section{A propos du droit d'auteur}

Les articles postulés doivent être originaux et non publiés, n’avoir aucun engagement éditorial en matière de publication ni faire l'objet d'une évaluation simultanée par une autre publication ou institution.

En cas d'utilisation de photographies ou d'images, les autorisations d'utilisation et de publication correspondantes doivent être envoyées à l'éditeur.

Lauteur ou les auteurs doivent autoriser la publication de leur texte en complétant et signant le document d'»Autorisation de publication en faveur de l'Université EAN». Ce document sera fourni par l'éditeur une fois que l'article aura passé avec succès les deux étapes d'évaluation et qu'il aura été approuvé pour publication.

Les auteurs des articles publiés dans la revue auront le droit de recevoir deux copies physiques du numéro dans lequel leur contribution est apparue.

En tout état de cause, le comité scientifique et de rédaction de la revue entend et déclare que les opinions exprimées par les auteurs relèvent de leur responsabilité exclusive. 


\section{Fréquence de publication}

La Revue Escuela de Administración de Negocios est une publication semestrielle publiant ses éditions comme suit :

- Janvier à juin.

- Juillet à décembre

\section{Politique de libre accès}

La Revue Escuela de Administración de Negocios offre un accès gratuit et permanent à ses contenus sur la base du principe d'échange mondial des connaissances. La publication ne demande aucun type de paiement ou compensation, ni pour l'application, l'évaluation, ou la publication d'articles.

Le contenu de la revue est indexé sous la licence de Creative Commons International Attribution-Non Commercial - No Derivative 4.0 International.

La Revue Escuela de Administración de Negocios permet aux auteurs d'archiver leurs articles publiés dans des référentiels thématiques ou sur des pages internet personnelles une fois la version PDF finale publiée sur notre plateforme. Lauto-archivage, la publication des manuscrits ou des versions antérieures à la mise en page des textes ne sont pas autorisées.

\section{Politique de conservation des archives numériques}

La conservation des archives numériques du revue est assurée par LOCKSS et CLOKSS.

\section{Indexation}

La revue est actuellement indexée dans les répertoires suivants : DOAJ (Répertoire des revues en accès libre), SciELO (Bibliothèque électronique scientifique en ligne), Redalyc (Réseau de revues scientifiques d'Amérique latine et des Caraibes), REDIB (Réseau ibéro-américain d'innovation et de connaissances scientifiques), EBSCOhost, EconLit et dans l'index national Publindex de Colciencias en catégorie B.

\section{Histoire de la revue}

La Revue Escuela de Administración de Negocios est née en 1986 partant d’une initiative institutionnelle pour la diffusion des connaissances des travaux scientifiques de ses enseignants-chercheurs. Depuis lors, la publication a connu plusieurs évolutions tels que la définition des sciences sociales comme champ d'action universitaire, l'économie et la gestion comme domaine thématique spécifique, l'ouverture de son espace aux enseignantschercheurs de différentes institutions et l'entrée dans le monde des publications numériques. 